\title{
PEMBELAJARAN BERBASIS KOMPUTER PADA MATERI FLUIDA STATIS UNTUK MENINGKATKAN KEMAMPUAN BERFIKIR KRITIS SISWA KELAS XI IPA DI SMA NEGERI 1 SIMPANG HILIR
}

\section{Neng Sriatun ${ }^{1}$ \\ Guru Biologi SMA Negeri 2 Simpang Hilir Email:nengsriatun@gmail.com}

\begin{abstract}
Abstrak. Penelitian ini dilatar belakangi oleh adanya tantangan global yang akan dihadapi oleh dunia pendidikan, sehingga guru perlu membekalkan beberapa kompetensi kepada peserta didik salah satunyayaitu kemampuan berfikir jernih dan kritis.Untuk melatih kemampuan berfikir kritis dilakukan upaya dengan menerapkan strategi pembelajaran berbasis komputer menggunakan simulasi PhET dan Adobe Flash pada materi fluida statis di kelas XI IPA SMA Negeri 1 Simpang Hilir. Penelitian tindakan kelas (PTK) dilakukan dalam 2 (dua) siklus. Hasil tes kemampuan berfikir kritis siswa melalui pembelajaran berbasis komputer diperoleh peningkatan sebesar 22,69\% dari siklus I dengan rata-rata $62,80 \%$ dan siklus II 85,49\%. Tanggapan siswa terhadap pembelajaran berbasis komputer antara lain: siswa merasa senang terhadap pembelajaran fisika $(86,79 \%)$, siswa tertarik dengan pembelajaran menggunakan simulasi komputer $(83,33 \%)$, dan siswa sungguh-sungguh dalam mempelajari materi fluida statis $(90,24 \%)$.
\end{abstract}

Kata Kunci : pembelajaran berbasis komputer, berfikir kritis

\begin{abstract}
This research is motivated by the global challenges that will be faced by the world of education, so teachers need to equip some competencies to students one of which is the ability to think clearly and critically. To train the ability to think critically efforts to implement a computer-based learning strategies using PhET simulations and Adobe Flash on a static fluid material in class XI IPA SMAN 1 Simpang downstream. Classroom action research (PTK) is done in two (2) cycles. The test results of students' critical thinking skills through computer-based learning obtained an increase of $22.69 \%$ from the first
\end{abstract}

${ }^{1}$ Neng Sriatun adalah Guru Biologi SMA Negeri 2 Simpang Hilir 
cycle with an average of $62.80 \%$ and $85.49 \%$ second cycle. The response of students to computer-based learning, among others: students feel happy about learning physics $(86.79 \%)$, students interested in learning using computer simulation $(83.33 \%)$, and earnest students learn the material in static fluid $(90.24 \%)$.

Keywords: computer-based learning, critical thinking

\section{PENDAHULUAN}

Pendidikan sudah selayaknya mendapat perhatian semua pihak dalam mempersiapkan sumber daya manusia agar terciptanya generasi penerus yang akan menentukan kemajuan bangsa dan negara. Tantangan eksternal yang dihadapi dunia pendidikan antara lain berkaitan dengan tantangan masa depan, kompetensi yang diperlukan di masa depan, persepsi masyarakat, perkembangan pengetahuan dan teknologi, serta berbagai fenomena negatif yang mengemuka.

Menurut Kemdikbud (2014), kompetensi masa depan yang perlu dibekalkan kepada siswa antara lain kemampuan berkomunikasi, kemampuan berpikir jernih dan kritis, kemampuan menjadi warga negara yang bertanggungjawab, kemampuan mencoba untuk mengerti dan toleran terhadap pandangan yang berbeda, dan memiliki kesiapan untuk bekerja. Kemampuan berfikir kritis siswa perlu dikembangkan sejak dini karena diperlukan dalam menghadapi persoalan dalam kehidupan sehari-hari. Kemampuan berfikir kritis dapat membantu siswa dalam membangun pengetahuan dan memecahkan masalah secara matematis dan logis. Sehingga perlu peran guru sebagai ujung tombak pendidikan untuk merancang proses pembelajaran agar dapat merangsang kemampuan berfikir kritis siswa.

Sesuai dengan cita-cita dari tujuan pendidikan nasional, guru perlu memiliki beberapa prinsip mengajar yang mengacu pada peningkatan kemampuan internal peserta didik dalam merancang strategi dan melaksanakan pembelajaran. Peningkatan potensi internal itu misalnya dengan menerapkan jenis-jenis strategi pembelajaran dan mengadakan variasi pembelajaran. Menurut Rosalin (2008), variasi dalam kegiatan pembelajaran dapat dilakukan dengan cara memberi variasi terhadap gaya mengajar; variasi dalam penggunaan media dan sumber belajar; variasi dalam pola interaksi dan variasi dalam kegiatan.

Variasi pembelajaran menurut amanat kurikulum adalah dengan menggunakan fasilitas teknologi informasi dan komunikasi (TIK).Perkembangn teknologi yang semakin pesat sehingga penggunaan berbagai instrumen TIK dapat diterapkan dalam pembelajaran fisika. Misalnya dengan simulasi komputer. 
Pemanfaatansimulasi komputer dalam proses pembelajaran merupakan bentuk variasi guru dalam mempermudah peserta didik memahami materi yang diajarkan.Karena peserta didik dalam menerima pengalaman belajar atau mendalami materi-materi pelajarannya masih banyak memerlukan bendabenda, kejadian-kejadian yang sifatnya konkrit, mudah diamati atau langsung diamati, sehingga pengalaman-pengalaman tersebut akan lebih mudah dipahami. Penggunaan simulasi komputer dalam pembelajaran dapat membantu peserta didik dalam memberikan pengalaman yang bermakna.

Salah satu materi dalam pelajaran fisika adalah fluida statis. Hasil belajar siswa pada topik fluida statis sebagian besar belum mencapai nilai Kriteria Ketuntasan Minimal (KKM). Perolehan nilai ulangan kompetensi dasar di SMA Negeri 1 Simpang Hilirpada tahun pelajaran 2013/2014 ditemukan hanya 7 dari 39 siswa $(17,95 \%)$ yang melampaui KKM, tentu hasil ini masih jauh dari yang diharapkan.

Penggunaansimulasi komputer juga diharapkan untuk menarik minat dan memotivasi siswa, dan melatih kemampuan berfikir kritis, jika dikembangkan dapat dimanfaatkan sebagai solusi alternatif dalam pembelajaran. Pembelajaran fisika yang diterapkan dalam penelitian ini adalah "Pembelajaran Berbasis Komputer pada Materi Fluida Statis untuk Meningkatkan Kemampuan Berfikir Kritis Siswa Kelas XI IPA di SMA Negeri 1 Simpang Hilir”.

Tujuan yang ingin dicapai dalam penelitian ini adalah untukmengetahui peningkatan kemampuan berfikir kritis siswa kelas XI IPA di SMA Negeri 1 Simpang Hilir setelah pembelajaran berbasis komputer pada materi fluida statis serta mengetahui tanggapan siswa terhadap pembelajaran berbasis komputer pada materi fluida statis.

Berpikir dapat diasumsikan sebagai suatu proses kognitif, yaitu berupa kegiatan mental untuk memperoleh pengetahuan. Proses berpikir dapat dikelompokkan dalam berpikir dasar dan berpikir komplek. Berpikir dasar merupakan gambaran dari proses berpikir rasional yang mengandung sejumlah langkah dari sederhana menuju yang komplek.

Robert Ennis menyatakan bahwa, berpikir kritis adalah pemikiran yang masuk akal dan reflektif yang berfokus untuk memutuskan apa yang mesti dipercaya atau dilakukan (Kowiyah, 2012). Masuk akal berarti berfikir didasarkan atas fakta-fakta untuk menghasilkan keputusan yang terbaik. Reflektif artinya mencari dengan sadar dan tegas kemungkinan solusi yang terbaik. Norris dan Ennis (dalam Stiggins, 1994) mengungkapkan satu set tahapan yang termasuk proses berfikir kritis, yaitu : (1) mengklarifikasi isu dengan mengajukan pertanyaan kritis; (2) mengumpulkan informasi tentang isu; (3) mulai bernalar melalui sejumlah sudut pandang; (4) mengumpulkan 
informasi dan melakukan analisis lebih lanjut, jika diperlukan; (5) membuat dan mengkomunikasikan keputusan.

Pembelajaran berbasis komputer berarti proses pembelajaran yang menggunakan alat bantu dan sumber belajar dengan sistem komputer atau mikroprosesor dalam mencapai tujuan pembelajaran.Pembelajaran berbasis komputer telah terbukti bisa lebih efektif dan efisien dalam mencapai tujuan pembelajaran (Musfiqon, 2012).

Wena (2013) mendefinisikan pembelajaran berbasis komputer adalah pembelajaran yang menggunakan komputer sebagai alat bantu. Melalui pembelajaran ini bahan ajar disajikan melalui media komputer sehingga kegiatan proses belajar mengajar menjadi lebih menarik dan menantang bagi siswa. Dengan rancangan pembelajaran komputer yang bersifat interaktif, akan mampu meningkatkan motivasi siswa dalam belajar.

Pembelajaran berbasis komputer dalam penelitian ini menggunakan simulasi program PhET dan adobe flash. Physics Education Technology atau PhET merupakan sebuah ikhtiar sistematis yang tanggap zaman terhadap perkembangan teknologi pembelajaran. PhET dikembangkan oleh Universitas Colorado di Boulder Amerika (University of Colorado at Boulder) dalam rangka menyediakan simulasi pengajaran dan pembelajaran fisika berbasis laboratorium maya (virtual laboratory) yang memudahkan guru dan siswa jika digunakan untuk pembelajaran di ruang kelas. Simulasi-simulasi dalam PhET tersedia secara gratis dan diunduh di alamat https://phet.colorado.edu/en/ simulations/category/physics. Sedangkan simulasi menggunakan program adobe flash diperoleh pada saat pelatihan guru. Contoh tampilan simulasi komputer menggunakan program PhET dan program adobe flash sebagai berikut :
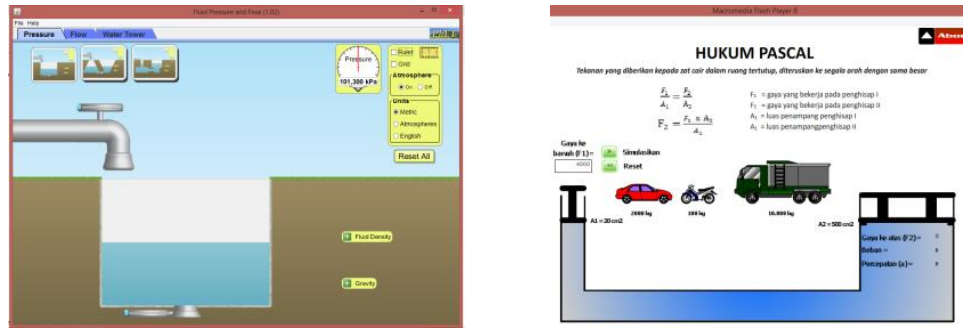

Gambar 1 Tampilan Simulasi Program PhET dan Adobe Flash

Keadaan bahan secara keseluruhan dapat dibagi menjadi zat padat dan fluida. Zat padat cenderung tegar dan mempertahankan bentuknya, sementara fluida tidak mempertahankan bentuknya tetapi mengalir. Fluida merupakan cairan yang dapat mengalir karena pengaruh gravitasi sampai menempati 
daerah terendah yang mungkin dari penampungannya, dan gas, yang mengembang mengisi penampungnya tanpa peduli bentuknya.

Standar kompetensi dalam penelitian ini yaitu menerapkan konsep dan prinsip mekanika klasik sistem kontinu dalam menyelesaikan masalah dengan kompetensi dasar menganalisis hukum-hukum yang berhubungan dengan fluida statik dan dinamik serta penerapannya dalam kehidupan sehari-hari. Sub materi fluida statis dalam pembelajaran berbasis komputer mencakup konsep Tekanan Hidrostatis; konsep Hukum Pascal; konsep Hukum Achimedes; dan konsep Terapung, Melayang, dan Tenggelam.

Secara umum aplikasi konsep fluida statis sering ditemukan dalam kehidupan sehari-hari siswa, antara lain : dongkrak hidrolik, rem hidrolik pada sepeda motor, pompa hidrolik ban sepeda, dan kapal besi dapat mengapung di air.

Berdasarkan uraian masalah, maka hipotesis tindakan dalam penelitian ini adalah: "Pembelajaran berbasis komputer pada materi fluida statis dapat meningkatkan kemampuan berfikir kritis siswa kelas XI IPAdi SMA Negeri 1 Simpang Hilir."

\section{Metode}

Penelitian ini berupapenelitian tindakan kelas (PTK) dimana guru melakukan tindakan melalui simulasi komputer yang terdiri dari dua siklus dengan dua kali pertemuan. Penelitian ini dilaksanakan di SMA Negeri 1 Simpang Hilir tahun ajaran 2014/2015, dilaksanakan di semester genap bulan April 2015. Subjek dalam penelitian ini adalah siswa/siswi kelas XI IPA yang berjumlah 35 orang.

Penelitian tindakan kelas terdiri dari empat kegiatan yang dilakukan dalam siklus berulang. Empat kegiatan utama yang ada pada siklus adalah (a) perencanaan, (b) tindakan, (c) pengamatan, dan (d) refleksi. Dalam tahap perencanaanPenelitian Tindakan Kelas (PTK) dilakukan langkah-langkah sebagai berikut: (1) menyiapkan Rencana Pelaksanaan Pembelajaran (RPP) dan Lembar Kerja Siswa (LKS); (2) tes berfikir kritis siswa berupa soal untuk mengetahui kemampuan berfikir kritis siswa setelah diberikan tindakan pembelajaran berbasis komputer. Soal berfikir kritis dikembangkan peneliti dengan membuat indikator soal berfikir kritis Norris dan Ennis; (3) angket tanggapan siswa skala Likert yang bersifat mengukur. Angket berupa pernyataan tertutup dengan empat pilihan wajib, yaitu sangat setuju, setuju, tidak setuju, dan sangat tidak setuju. Menurut Sukmadinata (2010), bentuk skala sikap dari Likert berupa pertanyaan atau pernyataan yang jawabannya 
dalam bentuk skala persetujuan atau penolakan terhadap pertanyaan atau pernyataan.

Tahap tindakan dengan memberikan pembelajaran berbasis komputer menggunakan program PhET dan program adobe flash, tahap pengamatan untuk melihat aktivitas belajar siswa, dan refleksi untuk mengevaluasi proses pembelajaran dan menentukan langkah tindakan selanjutnya. Penelitian tindakan kelas yang dilakukan ini dikatakan berhasil apabila sebanyak $80 \%$ dari jumlah siswa mencapai nilai kriteria ketuntasan minimal (KKM) 70 (dalam skala 100).

\section{Hasil dan Pembahasan}

\section{Peningkatan Kemampuan Berfikir Kritis Siswa}

Secara keselurahan hasil penelitian dari siklus I sampai siklus II hasil belajar siswa mengalami peningkatan seperti terlihat pada tabel 1 tentang peningkatan kemampuan berfikir kritis siswa.

Tabel 1 Rekapitulasi Peningkatan Kemampuan Berfikir Kritis Siswa

\begin{tabular}{|c|l|c|c|c|}
\hline No & \multicolumn{1}{|c|}{ Nama } & Nilai Pretest & Nilai Postest & Peningkatan \\
\hline 1 & Agung Setia Budi & 57 & 75 & 18 \\
\hline 2 & Aldi Lian Topan & 57 & 75 & 18 \\
\hline 3 & Aliyas Sufika & 43 & 75 & 32 \\
\hline 4 & Ari Wibowo & 43 & 63 & 20 \\
\hline 5 & Bangun Sudrajat & 71 & 86 & 15 \\
\hline 6 & Doni Sutris C. & 57 & 100 & 43 \\
\hline 7 & Ely Kristiani & 86 & 100 & 14 \\
\hline 8 & Fatmawati & 71 & 86 & 15 \\
\hline 9 & Febrianto & 71 & 100 & 29 \\
\hline 10 & Ferdiansyah & 71 & 86 & 15 \\
\hline 11 & Hendry & 57 & 86 & 29 \\
\hline 12 & Iskandar & 86 & 100 & 14 \\
\hline 13 & Jimmi Noor A. & 86 & 100 & 14 \\
\hline 14 & Jul Suriadi & 71 & 100 & 29 \\
\hline 15 & Jutilawati & 57 & 86 & 29 \\
\hline 16 & Karmila & 57 & 86 & 29 \\
\hline 17 & Kartika & 71 & 76 & 29 \\
\hline 18 & Kiki Trisna & 57 & 86 & 5 \\
\hline
\end{tabular}




\begin{tabular}{|c|l|c|c|c|}
\hline 19 & Leni Anjasari & 57 & 86 & 29 \\
\hline 20 & Maisari & 71 & 75 & 4 \\
\hline 21 & M. Saifullah & 86 & 100 & 14 \\
\hline 22 & Nadia Yunita R. & 29 & 63 & 34 \\
\hline 23 & Pranoto Aldi & 43 & 75 & 32 \\
\hline 24 & Rani Haryati & 57 & 86 & 29 \\
\hline 25 & Riduwan & 57 & 86 & 29 \\
\hline 26 & Riska Pratika & 57 & 86 & 29 \\
\hline 27 & Riska Ramadhan M. & 71 & 86 & 15 \\
\hline 28 & Rustam Efendi & 29 & 50 & 21 \\
\hline 29 & Septrina Dewi & 71 & 75 & 4 \\
\hline 30 & Siti Hatitin S. S. & 43 & 86 & 43 \\
\hline 31 & Sri Wahyuni D. & 86 & 100 & 14 \\
\hline 32 & Sri Wahyuni A. & 57 & 86 & 29 \\
\hline 33 & Supriyantiningsih & 43 & 86 & 43 \\
\hline 34 & Syuradi & 86 & 100 & 14 \\
\hline 35 & Tandi Davies & 86 & 100 & 14 \\
\hline \multicolumn{2}{|l|}{ Rumlah } & 2198 & 2992 & 794 \\
\hline Rata-rata & 62,80 & 85,49 & 22,69 \\
\hline \multicolumn{2}{|l|}{ Tuntas } & $45,71 \%$ & $91,43 \%$ & \\
\hline \multicolumn{2}{|l|}{ Belum Tuntas } & $54,29 \%$ & $8,57 \%$ & \\
\hline
\end{tabular}

Dari sajian hasil tes berfikir kritis siswa rata-rata nilai test pada siklus I 62,80 dengan nilai tertinggi 86 dan nilai terendah 29 (skala 100). Ada 19 siswa yang belum mencapai KKM dan 16 siswa yang sudah mencapai KKM. Data ini menunjukkan bahwa kemampuan berfikir siswa pada siklus I masih belum memuaskan.Siswa belum terbiasa berfikir dasar hingga kompleks dalam menyelesaikan soal aplikasi dalam kehidupan sehari-hari. Sehingga perlu dilatih kembalidalam proses befikir melalui pembelajaran berbasis komputer pada siklus berikutnya.

Pada siklus I rata - rata hasil belajar mencapai 83,97 sedangkan nilai KKM adalah 70 sehingga dapat disimpulkan bahwa tejadi peningkatan hasil belajar sebesar 21,17 point atau 21,17\%. Sedangkan untuk ketuntasan belajar siswa pada siklus pertama sebesar 45,71\% atau sejumlah 19 siswa. Pada siklus kedua meningkat menjadi $91,43 \%$ atau sejumlah 32 siswa.Peningkatan persentase kemampuan berfikir kritis dan ketuntasan belajar disajikan pada grafik 1 berikut ini. 
Grafik 1 Peningkatan Persentase Kemampuan Berfikir kritis Siswa dan Ketuntasan Belajar Tiap Siklus

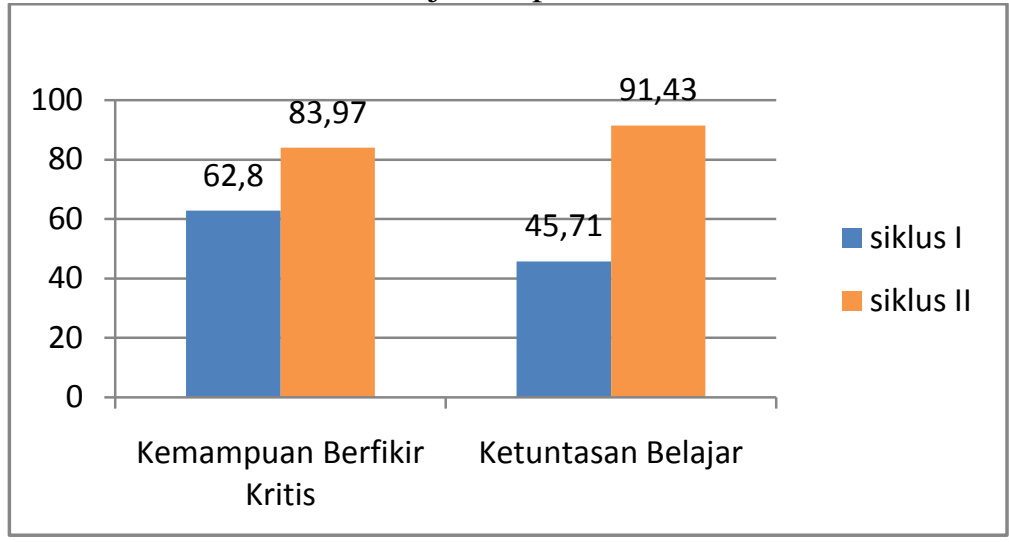

Hasil belajar siswa dan ketuntasan belajar siswa dari siklus pertama sampai siklus kedua mengalami peningkatan yang memuaskan. Berarti dapat disimpulkan bahwa pembelajaran berbasis komputer dapat meningkatkan kemampuan berfikir kritis siswa.

\section{Tanggapan Siswa Terhadap Pembelajaran Berbasis Komputer}

Hasil angket tanggapan siswa dianalisis dan dibuat dalam persentase. Persentase tanggapan siswa dirangkum seperti pada tabel berikut.

Tabel 2 Persentase Tanggapan Siswa Terhadap Pembelajaran

\begin{tabular}{|c|c|c|c|}
\hline No & Pernyataan & $\begin{array}{c}\text { Jumlah } \\
\text { Skor }\end{array}$ & Persentase \\
\hline 1 & $\begin{array}{l}\text { Saya merasa senang jika belajar menggunakan simulasi } \\
\text { komputer }\end{array}$ & 132 & $94,29 \%$ \\
\hline 2 & $\begin{array}{l}\text { Saya merasa tertarik untuk memahami materi fluida } \\
\text { statis }\end{array}$ & 121 & $86,43 \%$ \\
\hline 3 & $\begin{array}{l}\text { Belajar dengan simulasi komputer dapat membantu } \\
\text { mempelajari materi / bahan ajar }\end{array}$ & 128 & $91,43 \%$ \\
\hline 4 & $\begin{array}{l}\text { Belajar dengan simulasi komputer dapat membentuk } \\
\text { sikap kritis }\end{array}$ & 101 & $72,14 \%$ \\
\hline 5 & $\begin{array}{l}\text { Belajar dengan simulasi komputer dapat dijadikan } \\
\text { wadah untuk memahami konsep lebih sederhana dan } \\
\text { praktis }\end{array}$ & 124 & $88,57 \%$ \\
\hline 6 & Saya semakin faham dengan pembelajaran fluida statis & 120 & $85,71 \%$ \\
\hline 7 & $\begin{array}{l}\text { Saya senang dengan penilaian guru terhadap hasil kerja } \\
\text { saya }\end{array}$ & 122 & $87,14 \%$ \\
\hline
\end{tabular}




\begin{tabular}{|c|l|c|c|}
\hline 8 & $\begin{array}{l}\text { Saya yakin akan dapat berhasil mengikuti kegiatan } \\
\text { pembelajaran ini jika saya belajar sungguh-sungguh }\end{array}$ & 128 & $91,43 \%$ \\
\hline 9 & $\begin{array}{l}\text { Saya dapat menyelesaikan tugas-tugas dalam } \\
\text { pembelajaran ini }\end{array}$ & 114 & $81,43 \%$ \\
\hline 10 & $\begin{array}{l}\text { Pembelajaran menggunakan simulasi komputer perlu } \\
\text { diterapkan di sekolah }\end{array}$ & 125 & $89,29 \%$ \\
\hline
\end{tabular}

Dari sajian persentase tanggapan siswa terhadap pembelajaran berbasis komputer, persentase tertinggi $(94,29 \%)$ pada pernyataan siswa merasa senang jika belajar menggunakan simulasi komputer dan persentase terendah $(72,14 \%)$ belajar dengan simulasi komputer dapat membentuk sikap kritis siswa. Pernyataan ini merupakan fakta bahwa kemampuan berfikir ktiris siswa merupakan hal baru bagi siswa di SMA Negeri 1 Simpang Hilir. Berdasarkan kisi-kisi angket tanggapan siswa, hasil angket dikategorikan menjadi 3 (tiga) kategori seperti yang ditunjukkan pada gambar berikut ini.

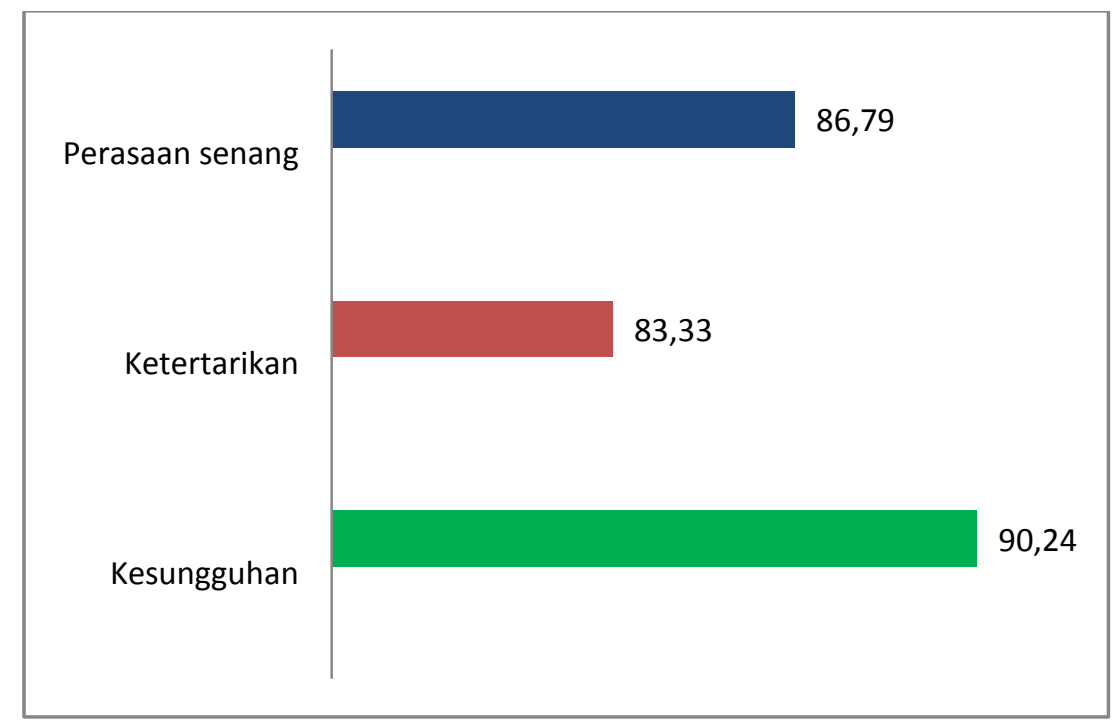

Gambar 2 Grafik Kategori Tanggapan Siswa

Siswa merasa senang terhadap pembelajaran fisika $(86,79 \%)$, siswa tertarik dengan pembelajaran menggunakan simulasi komputer $(83,33 \%)$, dan siswa sungguh-sungguh dalam mempelajari materi fluida statis $(90,24 \%)$.

Tanggapan siswa terhadap pembelajaran berbasis komputer pada materi fluida statis pada indikator perasaan senang terhadap pembelajaran fisika dengan persentase $86,79 \%$ (pernyataan nomor 1 , 7, dan 10) yaitu : merasa senang jika belajar menggunakan simulasi komputer, senang dengan penilaian 
guru terhadap hasil kerja siswa, dan pembelajaran menggunakan simulasi komputer perlu diterapkan di sekolah.

Siswa tertarik dengan pembelajaran menggunakan simulasi komputer (pernyataan nomor $2,3,4$ ) sebesar $83,33 \%$ pada pernyataan merasa tertarik untuk memahami materi fluida statis, belajar dengan simulasi komputer dapat membantu mempelajari materi / bahan ajar, dan belajar dengan simulasi komputer dapat membentuk sikap kritis.

Kesungguhan siswa dalam mempelajari materi fluida statis (pernyataan nomor 5, 6, 8, 9) sebesar 90,24\% dalam pernyataan belajar dengan simulasi komputer dapat dijadikan wadah untuk memahami konsep lebih sederhana dan praktis, semakin faham dengan pembelajaran fluida statis, siswa yakin akan dapat berhasil mengikuti kegiatan pembelajaran ini jika belajar sungguh-sungguh, dan siswa dapat menyelesaikan tugas-tugas dalam pembelajaran.

\section{SIMPULAN DAN SARAN}

Berdasarkan analisis data dan pembahasan dapat disimpulkan bahwa; (1).Hasil tes kemampuan berfikir kritis siswa melalui pembelajaran berbasis komputer diperoleh peningkatan sebesar 22,69 \% dari siklus I dengan rata-rata $62,80 \%$ dan siklus II 85,49 \% . Secara keseluruhan terjadi peningkatan yang positif terhadap kemampuan berfikir kritis siswadengan pembelajaran berbasis komputer; (2). tanggapan siswa terhadap pembelajaran berbasis komputer antara lain: siswa merasa senang terhadap pembelajaran fisika $(86,79 \%)$, siswa tertarik dengan pembelajaran menggunakan simulasi komputer $(83,33 \%)$, dan siswa sungguh-sungguh dalam mempelajari materi fluida statis $(90,24 \%)$.

Pembelajaran yang dilakukan dalam penelitian merupakan alternatif pembelajaran dalam melatih keterampilan berfikir kritis siswa, peneliti menyarankan: (1). Pembelajaran fisika hendaknya diajarkan dengan menggunakan simulasi PhET dan adobe flash untuk mempermudah siswa memahami konsep; (2). Dimensi kognitif dalam tataran kemampuan berpikir tingkat tinggi (Higher Order Thinking Skills), guru hendaknya melatih siswa dengan menerapkan dalam pembelajaran seperti berfikir kritis atau berfikir kreatif; (3). Penelitian tentang berfikir kritis siswa agar dilanjutkan baik tentang materi lain atau menggunakan metode yang lain yang sesuai.

\section{Daftar Pustaka}

Kemdikbud 2014 Materi Pelatihan Guru Implementasi Kurikulum 2013 Tahun Ajaran 2014/2015 Mata Pelajaran Fisika SMA/MA Jakarta BPSDMPK dan PMP 
Kowiyah 2012 Kemampuan Berfikir Kritis Jurnal Pendidikan Dasar Vol. 3, No. 5 - Desember 2012 : 175-179 http://journal.ppsunj.org/ jpd/article/ download/108/108diakses tanggal 24 Februari 2015

Musfiqon 2012 Pengembangan Media dan Sumber Pembelajaran PT. Prestasi Pustakaraya Jakarta

Rosalin Elin 2008 Bagaimana Menjadi Guru Inspiratif $\quad$ PT. Karsa Mandiri Persada Bandung

Stiggins R.J. 1994 Student-Centered Classroom Assessment Macmillan College Publishing Company, Inc New York

Sukmadinata Nana Syaodih 2010 Metode Penelitian Pendidikan PT Remaja Rosdakarya Bandung

Wena Made 2013 Strategi Pembelajaran Inovatif Kontemporer : Suatu Tinjauan Konseptual Operasional Bumi Aksara Jakarta 
